\title{
SECONDARY ANTIPHOSPHOLIPID SYNDROME REVEALED BY THE SUDDEN ONSET OF PNEUMONIA - CASE REPORT
}

\author{
Lazovic Biljana, ${ }^{1}$ Zlatkovic-Svenda Mirjana, ${ }^{2}$ Blazic Ivana, ${ }^{1}$ Kovac Jelena, \\ Detanac S. Dzemail, ${ }^{4}$ Milic Rade, ${ }^{5}$ Sarac Sanja, ${ }^{5}$ Detanac A. Dzenana, ${ }^{4}$ Zugic Vladimir ${ }^{6}$ \\ 'University clinical center "Zemun”, Belgrade, Serbia \\ ${ }^{2}$ Institute of rheumatology, Belgrade, Serbia \\ ${ }^{3}$ Radiology Clinic, Clinical Center of Serbia, Belgrade, Serbia \\ ${ }^{4}$ General Hospital Novi Pazar, Serbia \\ ${ }^{5}$ Military Medical Academy, Clinic for pulmonology, Belgrade, Serbia \\ ${ }^{6}$ Clinic for lung diseases, Clinical center of Serbia, Belgrade, Serbia, University of Belgrade, Serbia
}

Primljen/Received 05. 09. 2019. god.

Abstract: Introduction: Secondary antiphospholipid syndrome (SAPS) is APS that occurs in the context of another medical condition. Although antiphospholipid antibodies (aPL) can occur in patients with viral, bacterial, or protozoal infections, they are rarely associated with thrombosis.

Aim: To present an uncommon case of pneumonia and pleural effusion complicated with pulmonary thromboembolism in a patient with systemic lupus erythematosus (SLE), due to non-diagnosed secondary antiphospholipid syndrome.

Case report: A 28 years old woman, never pregnant, with a family history of systemic lupus erythematosus, has been suffering from SLE from the age of 18 . She had only articular and skin manifestations, without internal organ involvement. She has been taking Methotrexate (10 mg weekly) and Prednisone (5 mg daily) in the previous 10 years. She was presented at the Emergency department with the radiological finding of pleuropneumonia followed by temperature up to 39C, shortness of breath, cough, fatigue, and weakness.

Results: She was treated initially with three antibiotics and thoracocentesis. She developed pulmonary thrombosis without deep venous thrombosis. Laboratory findings were: $\mathrm{ESR}=37 \mathrm{~mm} / \mathrm{h}, \mathrm{CRP}=2+$, $\mathrm{ANA}=$ $1 / 80$ peripheral, RF negative, anti-dsDNA $=147$ (positive $>40$ ), anti-Sm negative, anticardiolipin IgG antibody 158 GPL (up to 12), anticardiolipin IgM antibody 5.5 MPL (up to 10), anti-beta2-glycoprotein IgG and IgM were negative and lupus anti-coagulant was 88 " $\left(18 "-55^{\prime \prime}\right)$. The patient underwent Heparin and Warfarin treatment, by checking INR to be in a 2.6 to 3.5 ran-
Prihvaćen/Accepted 29. 11. 2019. god.

ge. Prednisolone and Hydroxychloroquine were also started.

Conclusion: All patients suspected with SLE should be evaluated for antiphospholipid antibodies (APL). However, APS diagnosis requires both clinical and laboratory features.

Key words: secondary antiphospholipid syndrome, antibodies, systemic lupus erythematosus, autoimmunity, thrombosis.

\section{INTRODUCTION}

Antiphospholipid syndrome (APS)or Hughes Syndrome is an autoimmune disordercaused by the blood clots forming increased risk accompanied by one of antiphospholipid antibodies (APL): anticardiolipin antibodies (aCLA), anti-beta2-glycoprotein (GP1) antibodies and/or lupus anticoagulant (LA), registered in two or more occasions 12 weeks apart, resulting inarte$\mathrm{rial} /$ venous thrombosis and/or fetal loss $(1,2)$. APS can be primary-not accompanied by other autoimmune disorders and secondary-connected with mixed connective tissue disease, such as the systemic lupus erythematosus is $(2,3)$.

APS has a variety of manifestations: it can lead to metabolic syndrome $\mathrm{X}$, it can affect cardiovascular system leading to valve disease, accelerated hypertension and acute coronary syndrome or neurological system causing tinnitus, Morbus Meniere, family headache, migraine, myelopathy and epilepsy, it can have orthopedic manifestations such as spontaneous fractures, avascular necrosis, and algoneurodistrophy and pul- 

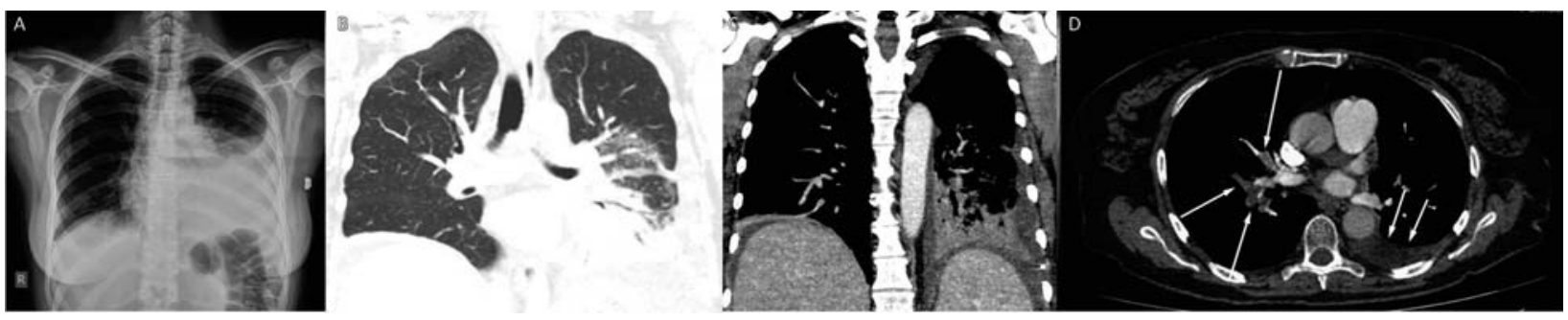

Figure 1. Consolidation of posterobasal and laterobasal segment of the left lower lobe with positive air bronchogram phenomenon and with pleural effusion at the same side consistent with pleuropneumonia. Additionally, ground-glass opacification within an apical segment of the left lower lobe is visible as a sign of inflammatory changes $(A, B, C)$; D) Pulmonary arteriography showing thrombosis of the right pulmonary artery

monary manifestations as well like embolic, primary and secondary pulmonary hypertension and thrombosis of the pulmonary artery (2). Pulmonary embolism may be the first APS manifestation and recurrent pulmonary emboli may lead to pulmonary hypertension (4).The aim of this study was to present an uncommon case of pneumonia and pleural effusion complicated with pulmonary embolism in a patient with systemic lupus erythematosus (SLE), due to non-diagnosed secondary antiphospholipid syndrome.

\section{CASE REPORT}

A 28 years old woman has been suffering from SLE from the age of 18 . She had only articular and skin manifestations, without internal organ involvement. She has not been regularly followed up, and her last evaluation at the Rheumatology Clinic was one year ago.She has been taking Methotrexate (10 mg weekly) and Prednisone (5 $\mathrm{mg}$ daily) in the previous 10 years. She was married, but never became pregnant. Her antiphospholipid antibodies were never checked up. She had a positive family history for SLE: her mother was diagnosed with it when she was 40 . The patient was presented atthe Emergency department with high temperature up to $39 \mathrm{C}$, shortness of breath, cough, fatigue, and weakness. On physical examination she was pale, but her hands were cyanotic. Auscultation has revealed decreased breath sounds, absent in the basal parts of the left lung. Her blood pressure was $120 / 80 \mathrm{mmHg}$ and heart rate $80 / \mathrm{bpm}$. Laboratory tests have shown leucocytosis of 15,9 x 1012/L(normal 4,4-11,5) withneutrophile (90\%)-normal 50-70\%, as predominant immune cell population, C reactive protein $180 \mathrm{ng} / \mathrm{ml}$ (normal less than 5), Ddimer $1500 \mathrm{ng} / \mathrm{ml}$ (over 500 must be evaluated for pulmonary embolism) and cholesterol of $6,7 \mathrm{ng} / \mathrm{ml}$ (up to 5,5). Other biochemical parameters were in a normal range. The chest X-ray detected consolidation in the basal part of the left lung, accompanied by pleural effusion (Figure 1-A). Arterial blood gases were withinthe normal range. The patient was started with triple antibiotic therapy (Ceftriaxone, Ci- profloxacin, Metronidazole), along with low molecular weight (LMWH) heparin twice daily. The first thoracentesis was performed on the second day of admission followed by the second one, 3 days later. The pleural fluid has revealed the exudative type, yellow-coloredwith negative culture and smear. Sputum culture was negative as well. On thefourth day, the patient was afebrile. Thoracocentesis repeated three times more until regression (Figure 1- A, B, C).CT pulmonary angiogram (CTPA) has revealed thrombosis of the right pulmonary artery (Figure 1-D). Color Doppler sonography oflower extremities has excluded deep venous thrombosis.Laboratory findings were: $\mathrm{ESR}=37$ $\mathrm{mm} / \mathrm{h}, \mathrm{CRP}=2+, \mathrm{ANA}=1 / 80$ peripheral, $\mathrm{RF}=$ Negative, anti-dsDNA $=147$ (positive $>40$ ), anti Sm negative, anticardiolipin IgGantibody $158 \mathrm{GPL}$ (up to 12), anticardiolipin IgM antibody 5.5 MPL (up to 10), anti-beta2-glycoprotein IgG and IgM were negative and lupus anti-coagulant was 88 " (18"-55"). Anticardiolipin test and lupus anticoagulantwere repeated 6 weeks later showing similar results. ANCA was negative, protein $\mathrm{C}$ and $\mathrm{S}$, antithrombin III and serum homocysteine were normal. The patient was diagnosed with antiphospholipid syndrome, secondary to systemic lupus erythematosus. According to guidelines, the patient underwent Heparin and Warfarin treatment, by checkingINR to be in a 2.6 to 3.5 range. Prednisolone and Hydroxychloroquine were also started. Dyspnea and cyanosis of the fingershaveimproved upon treatment.

\section{DISCUSSION}

All patients suspected with SLE should be evaluated for antiphospholipid antibodies (APL). However, APS diagnosis requires both clinical and laboratory features. If individuals are presented with APL only (without clinical manifestations) they are at less than $1 \%$ per year risk for the first time thrombotic event occurrence (5), and do not require specific treatment, but should be followed up. As compared to other APL, LA is the strongest predictor for both the arterial and veno- 
us thrombosis future event (6), although alone not significantly associated with the elevatedrisk for thrombosis. In patients who tested positive for both LA and anti-â2GPI antibodies(or anti-prothrombin), the OR of a first time deep venous thrombus event increased to 10.1 (95\% CI 1.3-79.8) (7). Some authors have recently shown that the žtriple positivity' (defined as simultaneous LA, aCL and anti-â2GPI positivity) carriesa higher risk for thrombosis (and adverse pregnancy outcome), as compared to patients with only one APL positivity. In 10 years of follow-up, over $30 \%$ of those patients had a thromboembolic event (8).

The highest rates of diagnostic and therapeutic ambiguities are present for APS secondary to SLE cases, as it is difficult to find the relationship between clinical manifestations, antiphospholipid antibodies presence and SLE complications for most of them (9). According to literature, the anti-phospholipid antibodies (APL) frequency in SLE ranges between 6 and 80\%. Some studies have indicated that $30-40 \%$ of SLE patients are presented with APL and third to half of them will develop APS (7).

\section{CONCLUSION}

For prevention of thrombosis, APS patients require long term Warfarin therapy withlow dose Aspirin and the INR range 2-3 for venous, or 3-4 for arterial and recurrent thrombosis. If APS associated with systemic lupus erythematosus, Hydroxychloroquine is effective for new thrombotic event prevention. Also, Hydroxychloroquine isrecommended for primary APS.
Abbreviation:
ANA - antinuclear antibody
aCL - anticardiolipin antibodies
APS - anti-phospholipid syndrome
APL - antiphospholipid antibodies
aCLA - anticardiolipin antibodies
anti-dsDNA - Double stranded DNA Antibody anti Sm - anti Smit antibodies which confirm SLE
ESR - erythrocite sedimentation ratio
GP1 - anti-beta2-glycoprotein lupus anticoagulant
LA - lupus anticoagulant
INR - international ratio
LMWH - low molecular weight
CTPA - CT pulmonary angiogram
SLE - systemic lupus erithematodus
RF - rheuma factor
MPL - anticardiolipin IgM antibody

Acknowledgment: None

Conflict of Interests: The authors declare that there are no conflicts of interest related to this article.

Funding: None

\section{Licensing}

This work is licensed under a Creative Commons Attribution 4.0 International (CC BY 4.0) License.

\section{Sažetak}

\section{SEKUNDARNI FOSFOLIPIDNI SINDROM OTKRIVEN KOD PACIJENTA SA PNEUMONIJOM - PRIKAZ SLUČAJA}

Lazovic Biljana. ${ }^{1}$ Zlatkovic-Svenda Mirjana, ${ }^{2}$ Blazic Ivana, ${ }^{1}$ Kovac Jelena, ${ }^{3}$ Detanac S. Dzemail, ${ }^{4}$ Milic Rade, ${ }^{5}$ Sarac Sanja, ${ }^{5}$ Detanac A. Dzenana, ${ }^{4}$ Zugic Vladimir ${ }^{6}$

\footnotetext{
${ }^{1}$ University clinical center "Zemun”, Belgrade, Serbia

${ }^{2}$ Institute of rheumatology, Belgrade, Serbia

${ }^{3}$ Radiology Clinic, Clinical Center of Serbia, Belgrade, Serbia

${ }^{4}$ General Hospital Novi Pazar, Serbia

${ }^{5}$ Military Medical Academy, Clinic for pulmonology, Belgrade
}

${ }^{6}$ Clinic for lung diseases, Clinical center of Serbia, Belgrade, Serbia, University of Belgrade, Serbia

Uvod: Sekundarni antofosfolipidni sindrom je APS koji se javlja u sklopu nekog drugog zdravstvenog stanja. Iako se antifosfolipidna antitela (aPL) mogu javiti kod pacijenata sa virusnim, bakterijskim ili protozoalnim infekcijama, retko su povezana sa trombozom.

Cilj: Cilj je prikazati neuobičajen slučaj pneumonije i pleuralnog izliva komplikovanog plućnom tromboembolijom, kod pacijenata sa sistemskim lupusom eritematozusom (SLE), zbog nedijagnostikovanog sekundarnog antifosfolipidnog sindroma.
Prikaz slučaja: Žena starosti 28 godina, bez anamnestičkih podataka o trudnoći, sa sistemskim lupusom eritematozusom u porodičnoj anamnezi, a od kojeg se leči od svoje 18. godine. Imala je samo kožne i zglobne manifestacije bolesti, bez oštećenja unutrašnjih organa. Tokom prethodnih 10 godina lečena je Metotreksatom (10 mg nedeljno) i Prednizonom (5 mg dnevno). Službi hitne pomoći se javlja sa radiološkim nalazom pleuropnemonije praćene temperaturom do 39 stepeni, nedostatkom daha, kašljem, umorom i slabošću. 
Rezultati: U početku je lečena sa tri antibiotika i torakocentezom. Razvila je plućnu trombozu bez duboke venske tromboze. Laboratorijski nalazi su bili $\mathrm{ESR}=37 \mathrm{~mm} / \mathrm{h}, \mathrm{CRP}=2+, \mathrm{ANA}=1 / 80$ periferno, RF negativan, anti-dsDNA $=147$ (pozitivan $>$ 40), anti-Sm negativan, antikardiolipin IgG antitela 158 GPL (do 12), antikardiolipin IgM antitela 5.5 MPL (do 10), anti-beta2-glikoprotein IgG i IgM su bili negativni, a lupus anti-koagulant bio je 88 " (18"-55"). Pacijentkinja je lečena heparinom i varfa-

\section{REFERENCES}

1. Miyakis S, Lockshin MD, Atsumi T, Branch DW, Brey RL, Cervera R et al. International consensus statement on an update of the classification criteria for definite antiphospholipid syndrome (APS). J Thromb Haemost. 2006; 4(2): 295-306.

2. Radin M, Sciascia S, Erkan D, Pengo V, Tektonidou MG, Ugarte A, et al. The adjusted global antiphospholipid syndrome score (aGAPSS) and the risk of recurrent thrombosis: Results from the APS ACTION cohort. Semin Arthritis Rheum. 2019; 49(3): 464-8.

3. Lazovic B, Zlatkovic-Svenda M, Jasarovic D, Stevanovic D. Systemic lupus erythematosus presenting as acute lupus pneumonitis. Arch Bronconeumol. 2018; 54(4): 222-3.

4. Maioli G, Calabrese G, Capsoni F, Gerosa M, Meroni PL, Chighizola CB. Lung Disease in antiphospholipid syndrome. Semin Respir Crit Care Med. 2019; 40(2): 278-94.

\section{Correspondence to/Autor za korespondenciju}

Biljana Lazović

University Clinical Center „Zemun“, Belgrade, Serbia Vukova 9, Zemun, 11080 Belgrade

Cell phone +38162212040

e mail addresses: lazovic.biljana@gmail.com rinom, uz proveru INR-a da bude u opsegu od 2,6 do 3,5. Započeta je i terapija prednizonom i hidroksihlorohinom.

Zaključak: Svi pacijenti za koje se sumnja da imaju SLE treba da budu testirani na antifosfolipidna antitela. Međutim dijagnoza APS zahteva i kliničke i laboratorijske karakteristike.

Ključne reči: sekundarni antifisfolipidni sindrom, antitela, sistemski eritematozni lupus, autoimunost, tromboza.

5. Ruffatti A, Del Ross T, Ciprian M, Bertero MT, Sciascia $\mathrm{S}$, Salvatore S, et al. Risk factors for a first thrombotic event in antiphospholipid antibody carriers: a prospective multicentre follow-up study. Ann Rheum Dis. 2011; 70(6): 1083-6.

6. Tektonidou MG, Andreoli L, Limper M, Tincani A, Ward MM. Management of thrombotic and obstetric antiphospholipid syndrome: a systematic literature review informing the EULAR recommendations for the management of antiphospholipid syndrome in adults. RMD Open. 2019; 5(1): e000924.

7. Lim W, Crowther MA, Eikelboom JW. Management of antiphospholipid antibody syndrome: a systematic review. JAMA 2006; 295 (9): 1050- 7.

8. Kato M, Hisada R, Atsumi T. Clinical profiles and risk assessment in patients with antiphospholipid antibodies. Expert Rev Clin Immunol. 2019; 15(1): 73-81.

9. Noureldine MHA, Nour-Eldine W, Khamashta MA, Uthman I. Insights into the diagnosis and pathogenesis of the antiphospholipid syndrome. Semin Arthritis Rheum. 2019; 48(5): 860-6. 